\title{
Translator Management: A Case Study of the Ming-Dynasty's Ethnic House
}

\author{
Ping Li \\ (D)/0000-0002-1666-1677 \\ Qufu Normal University, China \\ Chuanmao Tian \\ (D)/0000-0002-0677-9356 \\ Yangtze University, China \\ DOI: https://dx.doi.org/10.46679/978819484830104
}

\begin{abstract}
Translator management may be seen as the use of some management methods to manage translators in a certain environment so as to achieve a certain management purpose and improve operational efficiency. The present study applies contingency theory of management to the case study of translator management in the Ethnic House in the Ming Dynasty, focusing on its organisational designs, model of leadership, management methods, and needs and incentives. The findings show that there are no unified models for translator management methods, and today's translation companies and institutions are expected to follow certain management laws and make certain adjustments based on the external and internal environments as well as the qualifications and needs of managers and translators and establish a system of contingency management in order to promote the healthy and orderly development of the language service industry.
\end{abstract}

Keywords: translator management; contingency theory of management; Ethnic House; translator management methods; implications 


\section{This is a limited preview of the chapter.}

To read the full-text chapter, get access by purchasing this chapter or consider buying the complete book. If your library has subscription to EBSCOhost, the chapter including other chapters of the book can be accessed through your library.

This chapter is a part of the book, 'Contemporary Translation Studies' ISBN (paperback): 978-81-948483-0-1; ISBN (ebook): 978-81-948483-8-7

Book DOI: https://dx.doi.org/10.46679/9788194848301 


\section{Funding}

This work was supported by the National office for Philosophy and Social Sciences [grant no. 18BYY032].

Notes

(1) Ma Huan, 马欢, Retreived from

https://baike.baidu.com/item/\%E9\%A9\%AC\%E6\%AC\%A2/83656, on April, 12, 2020.

\section{References}

Birkinshaw, J., Healey, M. P., Suddaby, R. and Weber, K. (2014). Debating the Future of Management Research. Journal of Management Studies, (51):38-55.

Carothers, S. (2014). Translation Process Management: Best Practice. Franchising World, (3): 28-29.

Chen, Z. (1962). Anthology of Articles in the Ming Dynasty. Beijing: Zhonghua Book Company.

Chen, Y. (2015). On Translation Project Management. Industrial Technology \& Vocational Education, (2): 83-85.

China Translation Association. (2018). 2018 Chinese Language Service Industry Development Report. Beijing: China Translation Association.

Fayol, H. (1925). General and Industrial Management. Beijing: Beijing Institute of Technology Press.

Fiedler, F. (1967). A Theory of Leadership Effectiveness. New York: McGraw-Hill Book Company.

Ge, Z. (1987). The Earliest Foreign Language School in China: The Ethnic House in the Ming Dynasty. Foreign Language Teaching and Research, (2): 52-53.

Gouadec, D. (2007). Translation as a Profession. Amsterdam/Philadelphia: John Benjamins Publishing Company.

Guo, C. \& Xu, X. (2005). Research on Enterprise Boundary Management 
of Virtual Enterprises. Journal of HIT (Social Science Edition), (1): 69-72.

Hanson, E. M. (1979). School Management and Contingency Theory: An Emerging Perspective. Education Administration Quarterly, 15 (2): 98-116. doi: 10.1177/ 0013161X7901500209

$\mathrm{Hu}$, Q. (2018). The Ethnic House in the Ming and Qing Dynasty. Xiamen: Xiamen University Master Degree Thesis.

Jiang, S. (2010). Emperor Qin Shihuang. Changchun: Northern Women and Children Publishing House.

Kast, F. E. \& Rosenzweig, J. E. (1972). General Systems Theory: Applications for Organization and Management. Academy of Management Journal, (4): 460-482.

Kast, F. E. \& Rosenzweig, J. E. (1973). Contingency Views of Organization and Management. Chicago: Science Research Associates, Inc.

Kelly, N. (2015). Why Translation Management Is Broken, and How to Fix It. Multilingual, (2): 37-40.

Kokemuller, N. (2018). Disadvantages of Centralized Authority. Updated on April 13, https://yourbusiness.azcentral.com/disadvantages-centralized-au thority-7701.html, downloaded on May 12.

Liao, D. \& Sun, W. (2016). A Preliminary Study on the Ethnic House in the Ming Dynasty. Historical Review, (4): 79-88.

Lin, Y. et al. (1983). Si Ku Quan Shu: the Volume of History. Taipei: Taiwan Commercial Press.

Lommel, A. (2020). CSA: Chinese language service companies indicate the direction for the post-epidemic era. http://ex.chinadaily.com.cn/exchange/partners/82/rss/channel/cn/col umns/sz8srm/stories/WS5ed75c84a310f5a71bd20ac3.html, downloaded on June, 3.

Luthans, F. (1973). The Contingency Theory of Management. Business Horizons, (3): 67-72. 
Lyu, W., et al. (1995). The Revised Edition of the Ethnic House. In Gu Tinglong (ed.), Continued Revision of the Four Treasuries, pp. 530-656. Shanghai: Shanghai Ancient Books Press.

Ma, R. Wang, R. \& Zuo, X. (2013). Principles of Management. Beijing: People's Posts and Telecommunications Press.

McCabe, L. \& S. Atkin. (2016). Translation Management in a Continuous Delivery World. MultiLingual, (3): 55-59.

Ming Xianzong's Records. (1868). Zhengzhou: Xue Shi Zhai.

Pielmeier, H \& P. D. O'Mara. (2020). The State of the Linguist Supply Chain: Translators and Interpreters in 2020. https://insights.csa-research.com/reportaction/305013106/Toc?Se archTerms=translator\%20training, downloaded on July 6 .

Robbins, S. P. \& M. Coulter. (2010). Management. Englewood Cliffs, NJ: Prentice-Hall.

Schein, E. (2010). Organizational culture and leadership (4th ed.). San Francisco, CA: Jossey-Bass.

Scott, W. R. (1981). Developments in Organization Theory, 1960-1980. American Behavioral Scientist, (3): 407-422. doi:10.1177/000276428102400306.

Simon, H.A. (1977). The New Science of Management Decision. Englewood Cliffs. NJ: Prentice-Hall.

Sturdy, A., Clark, T., Fincham, R. \& Handley, K. (2009). Between Innovation and Legitimation-Boundaries and Knowledge Flow in Management Consultancy. Organization, (16): 627-653.

Tang, X. (1987). On Contingency Management School. Management World, (6): 57-72.

Tian, C. (2013). Types and Nature of Translators' Motives. Shandong Foreign Language Teaching Journal, (1): 93-98.

Te, M. (2009). A Brief Examination of the direction of the Ethnic House in the Ming Dynasty Before the Movement of the Capital. Journal of Ethnic and Frontier Studies, (12): 174-175. 
Wadango, B. \& Abdel-Kader, M. (2014). Contingency Theory, Performance Management and Organizational Effectiveness in the Third Sector. International Journal of Productivity and Performance Management, (6): 680-703. doi: 10.1108/IJPPM-09-2013-0161.

Wan, C. (2005). On culture in the Ming Dynasty. Nanjing: Nanjing Publishing House.

Wang, X. (1987). The Ethnic House in the Ming Dynasty and Its Cultivation of Translators. Ethnic Studies, (2): 62-69.

Wang, Y. \& Peng, R. (2008). Translation Management in the E Era. Proceedings of the 18th World Conference on Translation.

Wang, Z. (1908). A Study of the Ethnic House. Beijing: the Oriental Society. Wei, H. (2008). Path of Training Southeast Asian Language Talents Since the Ming Dynasty. Nanning: Master Thesis for Guangxi University for Nationalities.

Xie, G. (2003). Research on Ming Shi Lu. Wuhan: Hubei People's Publishing House.

$\mathrm{Yu}$, R. (1868). Manuscripts on the Ministry of Rites ( $94^{\text {th }}$ Volume: Remarks on the Tributes). Beijing: Siku Guan.

Zhang, M. (2011). Teaching Translator Ethnic and Foreign Languages Which Is Little but Significant. Chinese Science \& Technology Translators Journal, (2): 62-65.

Zhang, T. et al. (1974). History of the Ming Dynasty. Beijing: Zhonghua Book Company.

Zhang, W. (2012). Looking at the Cultural Exchange Between the Late Ming Dynasty and Siam from the Establishment of the Siam House. Southeast Asia, (11): 116-122.

Zhang, Y. (2014). Research on the Privilege System in the Laws of the Ming Dynasty. Lantai World, (7): 102-103.

Zhou, J. (2013). Research on the Organization System of the Ethnic House as the Earliest Translation Institution in China. Lantai World, (12): 139-140. 


\section{About the authors}

Ping $L i$ is an Associate Professor of translation studies at Qufu Normal University, Shandong, P.R. China, with a doctorate in Translation Theory and Translation Teaching from Beijing Foreign Studies University. She has published dozens of articles on translation and cultural studies in LANS-TTS (2016), Translation Horizons (2016), Journal of PLA University of Foreign Languages (2016), Foreign Language Research (2014).

Chuanmao Tian (corresponding author) is a professor of translation at Yangtze University with a PhD degree in Translation and Intercultural Studies. He is an advanced member of the Translators Association of China. His area of interest is translation theory and practice. He has published over ten articles concerning translation in major scholarly journals at home and abroad, such as Chinese Translators Journal (2000/2012), Across Languages and Cultures (2010/2014), Perspectives: Studies in Translatology (2008/2010), Critical Arts: South-North Cultural and Media Studies (2013), Continuum: Journal of Media \& Cultural Studies (2013), LANS-TTS (2016), Babel (2017), English Today (2017/2019). 